\title{
O KWARYP DE KANUTARI: UMA ABORDAGEM LINGUÍSTICA E ETNOGRÁFICA
}

Autor: Aisanain Paltú Kamaiurá

Ano de defesa: 2015

Orientadora: Ana Suelly Arruda Câmara Cabral

Instituição: Universidade de Brasília

Esta tese de doutorado consiste na descriçáo de um ritual do Kwaryp, realizada por um indígena que foi, ele mesmo, o "dono do morto" - Kanutari, seu pai e homem importante, fonte de conhecimento da tradição cultural Kamaiurá. Ao versar sobre essa edição específica do Kwaryp, Aisanain Paltu Kamaiurá focaliza, particularmente, a função educativa do ritual para os Kamaiurá e descreve estratégias retóricas usadas nos discursos do Kwaryp, aspectos que os tornam tấo eloquentes e didáticos. $\mathrm{O}$ autor presenta o ritual como um instrumento de renovaçáo da tradiçáo cultural e de identidade do povo Kamaiurá, assim como de fortalecimento das alianças dos Kamaiurá com outros povos alto xinguanos. A tese é uma contribuição importante aos estudos linguísticos sobre o Kamaiurá, por tratar tanto das estratégias retóricas como expressóes de modalidade, de aspecto, de interjeiçóes, quanto do uso intenso de simbolismo sonoro característico dos seus ideofones. Observa também que tais recursos, juntos, perfilam o modo respeitoso e poético por meio do qual os Kamaiurá se comunicam uns com os outros, em momentos solenes de sua história. É a segunda tese defendida no Brasil por um indígena sobre a sua língua nativa. 